\title{
Rehabilitating Martius: Audience Response to the Hero of "Coriolanus"
}

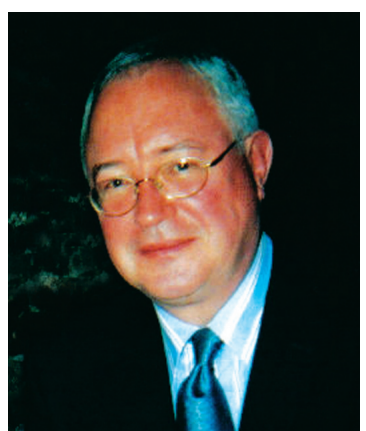

Terence McCarthy

y subject is Coriolanus but I would like to begin with Jane Austen. When she was about to start work on her novel Emma, Jane Austen wrote to her sister Cassandra "I am going to take a heroine whom no one but myself will much like" (Austen-Leigh: 203). I sometimes wonder whether Shakespeare ever wrote in similar terms to his sister when he was about to start work on Coriolanus "I am going to take a hero whom no one but myself will much like". I may be taking too much for granted: perhaps Shakespeare did not like Coriolanus much either, but in that case he must, at least, have liked the challenge of writing about such a disagreeable protagonist.

In fact, of course, Jane Austen's rather defensive remark turned out to be quite unnecessary, and the phrase is so famous precisely because it has been quoted so many times, but always to be contradicted. Most of us do like Emma Woodhouse. She is infuriating, of course; we would willingly wring her neck at times and we feel that $\mathrm{Mr}$ Knightley must have been a saint to marry her, but we like her. On the other hand, very few people ever like Coriolanus. A.P. Rossiter summed the matter up nearly fifty years ago: "there is no reason that I can see to like Coriolanus at any stage of the play" (Rossiter: 242). Perhaps we should just leave it at that and get on with other, more important things. After all, it is hardly the most sophisticated literary approach to talk about liking or not liking a particular character. Yes, we like Elizabeth Bennet, or Orlando and Rosalind, or the Wife of Bath, and personal reactions of the kind are only natural as we read. But they are not very profound, and sometimes the notion of liking can be totally inappropriate. We would not get far with Wuthering Heights if we had to like Heathcliff?' ${ }^{1}$ And yet I can't help feeling that, in the theatre, or in the Shakespearean theatre, personal response is an essential part of the aesthetic experience, an experience which does indeed involve an emotional commitment. These imitations of life arouse reactions that imitate reactions we have in life. We may respond differently in the theatre, but we do respond, and along similar lines. At a performance of Twelfth Night, we warm readily to the unbridled exuberance of Sir Toby Belch and are glad to see the po-faced Malvolio brought down a peg or two, even though, back in our appartment block, we would much rather have Malvolio as a next-door-neighbour. Well, at least $I$ would, especially at 3 o'clock in the morning. 
The problem for literary scholars is this: can we make a valid and intellectually satisfying literary judgement based merely on a question of sympathetic response; do we not feel more at-ease with our colleagues from the Science Faculties if we construct our readings of texts with a more solid theoretical grounding, preferably with reference to the great and good in academia: Lacan and Levi-Strauss, Barthes and Bakhtin, Derrida and (why not?) Freud. Saying that the problem with Coriolanus is that we don't like Caius Martius, the hero, is sure to bring a patronising smile to the lips of physicists or chemists, confirmed in their low opinion of what we call work. According to them, we read books, say whether we enjoy them and call it research. And yet in spite of the benign irony of our scientific colleagues, the fact remains that audience response to the hero of Coriolanus has had an effect on the play's reputation both in the theatre and in the classroom, and is something the literary scholar cannot merely ignore.

Basically, I would suggest, we must refuse to be browbeaten by our colleagues from the Science Faculties and have the courage of our convictions. They do not have the monopoly on learning. Our research is different from theirs, but so what? And the expression "Scientific Knowledge", included in the title of this conference, is somewhat provocative-and a trifle tautological. It says the same thing twice, for what is science if not knowledge? Unless the knowledge of so-called "scientists" is better than ours. They, of course, think it is. We are frequently reminded that our research serves no purpose (I have avoided the word "useless") even though our scientific colleagues, with a little modesty, ought to be more ready to admit that much of their research leads nowhere and serves no purpose at all. But, of course, the mere fact of knowing that - that they have reached a dead-end - is, in itself, knowledge, and all knowledge - useful or not - is important. Even ours. That's why I have become very ill-at-ease with all the pseudoscientific vocabulary that literary researchers arm themselves with as a kind of salve to their conscience or a self-defence, especially those who insist on referring (frequently) to their travaux scientifiques. They mean their academic work, but the word "scientific" has greater cachet. You will understand why I am so pleased that at our present conference here in Yerevan we are divided into seminars and panels - plain, unpretentious words. So often literary gatherings are split into workshops and ateliers, while in France, I belong to a laboratoire de recherche no less. Soon we will all be wearing white lab-coats. I wonder if I should get myself a bunsen-burner and a few test tubes, just in case...

My heavy-handed irony makes it quite clear that I persist in believing that literary scholarship is a valid university discipline and that we should not allow ourselves to be marginalised, to become a sort of poor relation, the Fanny Price of academia, present on sufferance and fed with the scraps that fall from the overflowing research budgets of the science faculties. We have no cause to be ashamed of our work in the Arts, which has both its own specificity and its own validity. Perhaps, indeed, the trouble started when we did nothing to prevent our universities from being divided into Arts and Science Faculties, as though the Arts were not science. Personally I take comfort from the recollection that my first university, Cambridge, still awards no science degrees. Students of Chemistry and Physics may belong to the Faculty of Natural Sciences, but they are awarded a B.A. - Bachelor of Arts - in line with the ancient tradition in which the Seven Liberal Arts were the basis of all science. 
And so - for you were beginning to think that I would never return to Coriolanus - if Shakespeare has chosen to present a thoroughly disagreeable protagonist who seems entirely indifferent to the good opinion and approval not only of everyone around him on stage (except perhaps his mother), but also in the audience, this places spectators (and readers) in a challenging position; how are we meant to react? The aesthetic impact is one we are justified in examining. Are we meant to like Martius or not? Unsophisticated as the question may be, it is one the play invites, indeed, forces us to ask.

Perhaps we could merely argue that in the medieval tradition tragedy presents the fall of a great - but not necessarily admirable - man. Nero, for example, is famously to be found in the list of tragic heroes provided by Chaucer's Monk (Chaucer: 195). Alternatively, we might say that military greatness, as such, commands our admiration. After all, what more does Macbeth have before he goes off the rails? In Elizabethan eyes, achievement in combat was, in itself, a moral quality, and indeed, down until the midtwentieth century a man in uniform incited respect and admiration. He had, de facto, charisma, not to mention sexual attraction. Just ask Lydia and Kitty Bennet, who were moths around a flame when there were officers billeted in town

But even though we acknowledge Martius's military exploits - and Shakespeare, unusually, spends most of a long first act presenting them before our eyes (not merely in reported narrative) - we never accord more than our token admiration. Macbeth elicits our sympathy in a way that Martius, another "Bellona's bridegroom" (1.2.55), if ever there was one, does not. From the start we genuinely dislike him. And Shakespeare seems to take positive steps to ensure our disapproval.

At first this might not seem true since, although the plays opens with uncompromising criticism of Martius, the attacks are put into the mouths of a violent mob. Martius is declared to be "chief enemy to the people" (1.1.7-8) and "a very dog to the commonalty" (1.1.26), but these common people are not the likeable, witty plebeians in party mood who open Julius Caesar2: they appear carrying "staves, clubs, and other weapons", as the first stage direction of the play says, and the potential danger that they represent is so theatrically obvious - Coriolanus "is unique among plays of the period in opening with a scene of public violence", Philip Brockbank reminds us (Brockbank, Arden: 95) - that Shakespeare seems to be arousing our initial sympathy for Martius, and the objection "He hath faults, with surplus, to tire in repetition" (1.1.42-43) sounds like one of those vast and vague exaggerations which show that the accusations are inflated and ill-founded. As it turns out, this initial sympathy is something of a red herring, for any good feelings we might be ready to have for Martius are shattered as soon as the man himself walks on stage.

Martius has barely reached the end of his first iambic pentameter before he is hurling abuse at the crowd of "dissentious rogues" (1.1.161), and the moral disdain and physical repulsion that he feels for the plebeians are expressed without compromise and at considerable length. Later, when he is persuaded to stand for office, the idea that he must curry favour with the people to earn an election that he considers he has already, and amply, earned is anathema to him, and he dismisses the calls from family and friends for a more diplomatic approach to playing the political game, as though it were the direst 
form of corruption. Rubbing shoulders with the masses can only contaminate and Martius expresses his repugnance without caring who hears him.

In twenty-first century terms, Martius is outrageously politically incorrect, but it will not do merely to invoke the different attitudes of Elizabethan England with its more rigid hierarchy. For even by Shakespearean standards there is something decidedly distasteful about Martius and his political agenda. Other people in Shakespeare's plays express moral and physical contempt for the masses, but we are not called upon to admire them. Richard II is not seen to his advantage when he despises his people and accuses Bolingbroke of base sycophancy for lowering himself to seek popular support (1.4.20-36). Perhaps most of all we remember that Queen Elizabeth herself spoke frequently of her love for her people and valued their love for her. Elizabeth's love may have been more verbal than practical - one of her courtiers might have adapted Menenius's words to her:

[she] loves [her] people,

But tie [her] not to be their bedfellow. (2.2.62-3).

But Martius never even manages to pay lip service to any fabricated love for the crowds. Of course, Elizabeth was dead by the time Coriolanus was written, but the initial years of disenchantment that followed immediately on her death, at a time when London was welcoming James with enthusiasm, gradually - as Teresa Bela has shown (Bela: passim) - gave way to nostalgic affection for Gloriana as the new monarch turned out to be a disappointment. For James never sought or valued the affection of his people.

In our age, we have grown used to the play-acting of politicians ${ }^{3}$, who find time to kiss babies and shake the hands of workmen during election campaigns but who withdraw to their political ivory towers far from dribbling infants and soiled labouring hands once the votes have been counted. We are not therefore shocked when Martius's entourage calls on him to play the game and go through the usual electioneering motions like all his predecessors. That Martius refuses and protests an unbending integrity should perhaps give us pause, should make us ashamed of our laxism in the face of such patent political hypocrisy. But in fact it does not. It is, rather, Martius's brand of honesty that is misplaced. Menenius, exasperated, pays tribute to Martius with the famous words "His nature is too noble for the world" (3.1.257). But this means not only that Martius stands out; more importantly it means that he cannot fit in.

Martius's unbending integrity hides a total lack of political awareness and human understanding. He tells the plebeians to their face what he thinks of them and expects them to give him credit for his honesty. At times he appears frankly obtuse, as though he has never thought things through. I am reminded of a remark once made - I have forgotten by whom - about Mrs Thatcher: "when she speaks without thinking, she says what she thinks". The same is eminently true of Martius, who is ultimately something of a political liability. Another name for candour is misjudgement, and no statesman should ever speak without thinking. In Act 3, Martius quite simply talks himself out of the statesman's job. 
All he has to recommend him as a leader is his military achievement, and even there he is too noble for the world. His exploits are exemplary, excessive - as we say today, over the top. He does not inspire his men by his example; what for him is bravado is, for them, mere "foolhardiness" (1.5.17), and they let him go it alone, which is ultimately what he prefers. Martius is a killing machine daubed in blood. He does not encourage his men with generosity of spirit and reward their feats, like Antony; he is unready to accept lesser achievements than his own and he goads his men into battle with threats. In Act 1 scene 8, he does seem to inspire his men and attracts a group of volunteers to go along with him. For once he even speaks warmly to ordinary soldiers, but Cominius thinks the initial enthusiasm will subside and that in the end they might not "make good this ostentation" (1.8.87). In war as in peace, he can only set himself apart. Coriolanus is, quite simply, the hero who has difficulty belonging. He is intensely aware of the plebeians as the enemy, the "them" who are opposed to the nobility he represents. But Martius never gets round to saying "us"; the first person singular pronoun is the one with which he is most at ease. And while Shakespeare reveals his greatness, he also reveals him for what he is - a man who lives in the public eye and who has never had time for a private life.

Right at the beginning of the play, Shakespeare interrupts the opening political and military scenes to show the domestic setting to which the hero belongs - we meet the hero's mother and wife. But the scene, one of Shakespeare's inventions, is also one of Shakespeare's red-herrings, for all it seems to provide Martius with is a non-existent domesticity. Even as a boy, he had been sent away from the pleasures of a home life by his mother, and, to be flippant, one might "venture to assert that [Martius] [n] ever called [her 'Mummy'] ${ }^{4}$. He was given an education in destruction by a matriarch who values family honour more highly than filial affection and who is already preparing the next generation of killers with her grandson, a little thug who "mammocks" (1.3.68) butterflies. Martius is such a stranger to domestic comfort that his idea of utter defeat for the enemy is to "beat them to their wives" (1.5.12), back to the company of women that emasculates a man and undermines his status as a soldier, which is all that seems to be of interest to Martius ${ }^{5}$. The Shakespearean hero has doubts and questions his motives, but not Martius, and the solitariness of his position both in military exploit and political theory never, for one moment, makes him wonder whether he might not be wrong. This is, perhaps, why we never quite admire his singlemindedness of purpose: it has never been put to the test.

Nothing in the first part of the play warms us towards Martius, who is a public figure without a private persona. So many of Shakespeare's plays show the conflict between the function and the individual: inside the public man is a private man trying to get out and express himself. But inside Martius there is no one-like Italo Calvino's cavaliere inesistente. With Martius, what we see is what we get. None of those outrageous public declarations is ever toned down or given greater nuance by the expression of private hesitations and doubts when he is alone. It is as though Martius has no hesitations and doubts and it is for this reason that Shakespeare never gives him a soliloquy. He would not know what to do with one. I am exaggerating in fact: Martius 
is, indeed, given a soliloquy in Act 4 (scene 4, 1-6 and 12-26), but instead of expressing his doubts and fears, the hesitations and regrets now that he has reached Antium and is about to make a momentous decision, instead of confiding in us to give us a clearer picture of himself, he merely uses his soliloquy first to describe the scenery and then to blame the "slippery" world for forcing him to do what he has already decided to do. If he had any doubts, he dispensed with them in the wings, while he was waiting to come on stage.

If the play had continued like this it could hardly be expected to function as a tragedy. Martius's death would have little or no impact because he has never been allowed to arouse our interest, let alone our sympathy. When a tragic hero dies and we just do not care, or do not care much, there is something theatrically wrong. We expect a sense of loss or waste, the feeling that things will not be the same again, that a whole age has gone, that the world continues but in little. With Richard III, perhaps, there is even a thrill of satisfaction. But we do not expect to leave the theatre after a tragedy with no more than a shrug of the shoulders.

In fact, by the time Martius gets his soliloquy, he has already changed - or rather Shakespeare's method has changed and he allows us to see a different Martius. The break comes right at the beginning of Act 4 . There are those who believe that the act division between 3 and 4 as it stands in the 1623 Folio text is unlikely to be by Shakespeare. The first two scenes of Act 4 are clearly part of the aftermath of the banishment, they suggest, and the real break comes (as it is often placed in performance) with Act 4, Scene 3, when the action moves from Rome to Antium and some time has passed. Personally, I am not convinced and would prefer not to quibble with the Folio's act division. Not only does Act 3 come to an end at a dramatic high point, but Act 4 presents us with an entirely new Martius, who has changed considerably in spite of his disclaimer to his family and friends:

While I remain above the ground you shall

Hear from me still, and never of me aught

But what is like me formerly (4.1.52-4).

The full ironic force of the change comes later when Martius goes over to the other side and, de facto, becomes their leader, as though he were realising that ambition he had so ominously voiced at the beginning of the play in reference to the Volscian leader, Aufidius:

Were I anything but what I am

I would wish me only he. (1.1.229-30).

At the beginning of Act 4, that wish has not yet come true, but none the less we discover a Martius who is by no means "like [himself] formerly".

The difference comes with defeat, although it does not appear at once. When Martius is banished by the plebeians, there is defiance on his lips. He refuses to give up the initiative and he banishes them, just as he refuses to admit the loss of his homeland, 
by proclaiming "there is a world elsewhere" (3.3.136). But like it or not, he has been defeated and it is when he has, indeed, lost the initiative and is no longer giving orders that we begin to see Martius the man. Now that he has been forced out of public life, the private man has time for other things. Defeat, as it were, makes him human, cuts him down to size. Defeat is something he knows nothing about and when he tastes it he tastes common humanity. He sees how the other half live. Being rejected by the people has made him think again, just as earlier in the play, being rejected by his mother made him relent (3.2.125-30).

Martius's career has been devoted to distinguishing himself, to being better than anyone else, to being different. He is used to being given "the whole name of the war" (2.1.132). His great victory at Corioles is achieved single-handedly, and his final boast is "Alone, I did it" (5.6.117). And as Martius regularly rejects the shared patterns or principles that the Roman patricians have accepted, as he refuses all compromise, he surrounds himself with the solitude of higher standards and constantly cuts himself off.

But now, when the people cut him off, he finds a more ordinary and shared humanity, and in Act 4 scene 1 we discover a new man who sees the situation with almost bemused irony. "The beast/ With many heads butts me away" (4.1.1-2), he remarks wryly and, instead of pouring scorn on the masses and on the weakness of the patricians, as he did in Act 1 scene 1 and Act 3 scene 1, he is full of consideration for his family and friends. It is not they who console him, bid him to take heart and keep his spirit up; he does the consoling, and with considerable affection, chivvying them up almost teasingly with that ironic promise that he will not change: he will still be the same old Martius whatever happens (4.1.52-4). Except that, in a way, he has changed already.

His role has certainly changed, and significantly so. Until now he had been the great hero who defends the city, a Jack the Giant killer single-handedly protecting the community against a villainous enemy, but when he is banished, when Rome turns its back on him and he on Rome, we realise that although perhaps he was not quite a Jack a simple widow's son - he has certainly become the giant. The image Shakespeare uses is a little different: Martius is the dragon in its fen, a dormant threat. This is how he sees himself (4.1.31) and how others see him (4.7.23 and 5.4.13) He is no longer Beowulf; he has become Grendel, and when Martius is more the scourge than the saviour, Shakespeare suddenly seems to be on his side. One is reminded of the splendid phrase C.S. Lewis used to characterise Tamburlaine, "a hideous moral spoonerism: Giant the Jack killer." (Lewis 1954: 52). There is something of a similar feeling in the second half of Coriolanus.

Martius sees himself as the lurking monster, but, at the same time, we become aware that the outcast hero has a humanity we never noticed in Martius the Roman. He is certainly not the man he used to be. And the same can be said about Volumnia: she is not the man she used to be either. Defeat has brought out the feminine, vulnerable side in her: she needs comforting and Martius shows himself to be a caring and attentive son. In the next scene, with the Tribunes, she continues to revile and curse but her sting, as it were, has been drawn. Back in Act 2, scene 1, the Tribunes kept out of her way, too insignificant to merit her attention and appear in her presence; by Act 4, scene 2, they have no need to sidle away or feel inferior. It is they who walk off, no longer willing to give her the time 
of day. In defeat, Volumnia has gone to pieces. The daunting dowager has become merely dotty, if I may imitate the scornful alliteration they use to dismiss her:

\author{
Why stay we to be bated \\ With one that wants her wits. (4.2.46-7).
}

They are wrong, of course, but she is, none the less, diminished.

The same human, as opposed to heroic, virtue is in evidence at the end of the play when the women come in the envoy. Martius has been implacable with Cominius and Menenius, relenting only by sending letters. But personal values come to the fore as soon as the women arrive., Virgilia, as Martius's wife, comes first, as of course she should, no longer playing second fiddle to her domineering mother-in-law, and the tribute she receives is full of devoted, romantic attachment (5.3.27-8 and 44-48, for example). At last we understand the feelings Virgilia expressed in Act 1 scene 3, and we suspect that Martius cannot have given up "the embracements of his bed" (1.3.4), as readily as Volumnia imagines. The tribute to his mother is equally fitting and moving, while Martius speaks to his little son with the kind of warm, fatherly affection - "that's my brave boy" (5.3.77) - full of the proud encouragement that must surely have been better for the lad than all Volumnia's incitations to violence. Martius himself is so touched by what he sees that he describes it all to himself as it happens in a series of half-soliloquies that suggest that he did know, after all, about the possibilities that the soliloquy has to offer. We see a man who learns what belonging means as he sees those who belong to him coming to beg for mercy. He realises that his ideal of being "author of himself", a man that "knows no other kin" (5.3.36-7) is quite untenable.

Act 5 scene 3 offers a scene of an emotional intensity we have not witnessed before. The uncompromising, inhuman, political and military values give way to the shared values of common humanity, while the very last scene of the play, when Martius returns to Antium, shows another aspect of the hero that warms us to him but, of course, too late. The invincible Martius becomes the vulnerable Martius. He returns to Antium with the support of the people (a detail not found in Plutarch) and for once he has no scornful invective for them, apparently aware at last of the value of popular support. But he is no longer in control. He returns with an assurance that he has acted well, and, for once, not by "run[ning] reeking o'er the lives of men as if/ 'Twere a perpetual spoil" (2.2.117-8), not by shedding blood but by avoiding bloodshed, by reaching a compromise, by taking into account - as he has not done so far - the opinions of others.:

\title{
We have made peace \\ With no less honour to the Antiates Than shame to th' Romans (5.6.79-81)
}

But his self-assurance has made him vulnerable; his own right-doing has made him blind to the deviousness of others. And as he dies, we remember that he is, indeed, a man of integrity, a man not open to corruption, a man of his word, a man who can be trusted where others cannot. In this he has distinguished himself, but Martius has an innocence that his own nobility of spirit imposes on him, and he misreads the political situation to the very end. He fails to see what is coming. 
By the end of the play, Shakespeare has manipulated our sympathies and presented the erstwhile disagreeable Martius in such a way that his death arouses a personal reaction that is all the more essential to the impact of the play in that it is by no means what we have been led to expect. We are still not allowed to forget what, in the past, Martius stood for and, indeed, the final words of the play call to mind the widows and "unchilded" women (5.6.152) he has so grievously offended. But the "noble memory" (5.6.154) he has earned seems eminently fitting. Although his enemies pour scorn on the "boy of tears" (5.6.103) who puts personal sentiment before military obligations, we realise that Martius has finally endorsed the values of family and community, which he seemed so often to dismiss, the shared values of one who, at last, realises what is meant by belonging. As Aufidius takes his devious revenge, it is valour itself that weeps, and valour, the highest virtue Rome had to offer (2.2.82), represents ideals that Martius clearly embodied.

The question of liking or not liking Martius, which may have seemed so trivial, so unscientific, is one that cannot simply be dismissed, and however much the kind of research undertaken by our colleagues from the Science Faculties seems to set the standard for all academic endeavour, the literary historian has the right to claim the specific nature and value of his own field of study. Our analyses of texts involve close, sensitive and, above all, informed reading. The examining, sifting and weighing up of evidence require experience, training, and considerable background knowledge and form the basis of a justifiable academic discipline we are not just reading books and saying whether we enjoy them. That we enjoy our work as I hope we do - does not undermine its value. If our scientific colleagues do not find enjoyment in their work, that is not our fault. The contemporary paradigm of scientific knowledge leaves ample place, I am convinced, for language and literature.

\section{Notes:}

1. Personally, I do not like Hamlet, at least not until he returns from England. Hamlet is a play like Coriolanus: the hero is presented backwards, as it were. We only start liking him when it is too late. I would like to thank my friend and former colleague, Dr. Margaret Tomarchio, for her careful reading of this paper and for making many helpful suggestions.

2. And even they are potentially dangerous, as Cinna the poet finds out.

3. And throughout Coriolanus the political game is seen in images of theatrical performance.

4. I am, of course, adapting a remark made by C.S. Lewis's private tutor to characterise the somewhat dour nature of John Milton: "I would venture to assert that no human being ever called him Johnnie" (Lewis 1966: 64 and, for the complete letter, Lewis 2004: 563).

5. Some editors suggest that Martius and his men will get to their enemies' wives first, but this idea of the sexual rewards of warfare fits ill with Martius's integrity. When he speaks of "that kiss/ I carried from thee, dear, and my true lip/ Hath virgined it e'er since" (5.3.46-8), I see no reason to doubt his words. 


\section{References:}

1. Austen-Leigh, J.E. (1926) A Memoir of Jane Austen. / Ed. by R.W. Chapman. London: Oxford University Press.

2. Bela, T. (2000) 'The Queen is Dead, Long Live the Queen': Eulogy and Nostalgia in Jacobean Literature // Les Débuts de siècles. / Ed. by Terence McCarthy, Dijon: UFR de Langues et Communication.

3. Brockbank, P. (ed.) (1976) Coriolanus. Arden edition. London: Routledge.

4. Chaucer, G. (1957) The Complete Works of Geoffrey Chaucer. / Ed. by F.N. Robinson. London: Oxford University Press.

5. Lewis, C.S. (1954) English Literature in the Sixteenth Century Excluding Drama. Oxford: Clarendon Press.

6. Lewis, C.S. (1966) Letters of C.S. Lewis. / Ed. by W.H. Lewis, London: Geoffrey Bles.

7. Lewis, C.S. (2004) The Collected Letters of C.S. Lewis, Family Letters 1905-1931. / Ed. by Walter Hooper. New York: HarperSanFransisco.

8. Shakespeare, W. (1994) Coriolanus. / Ed. by R.B. Parker. Oxford: Oxford University Press.

9. Shakespeare, W. (2002) King Richard II. / Ed. by C.R. Forker. Arden edition. London: Thomson.

10. Shakespeare, W. (1951) Macbeth. / Ed. by Kenneth Muir. Arden edition. London: Methuen.

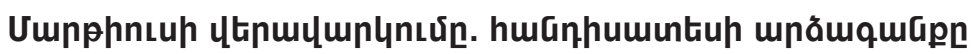 unnpnLuah htinnupa}

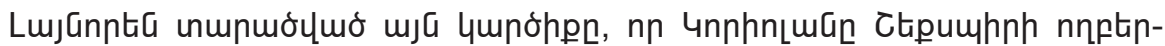

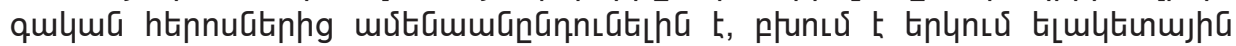

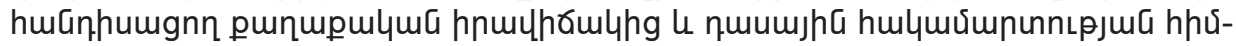

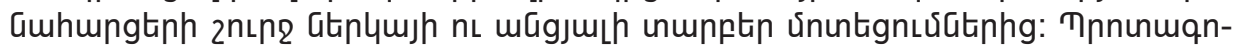

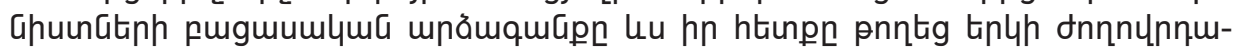

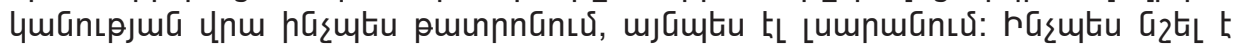

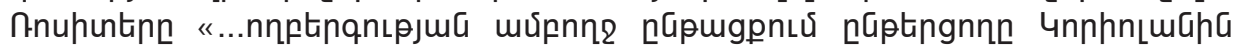

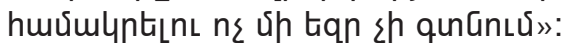

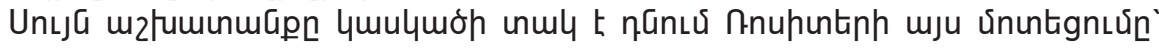

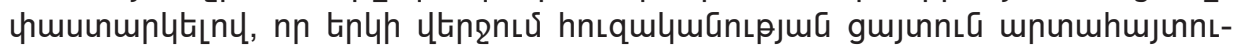

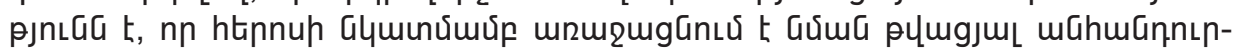

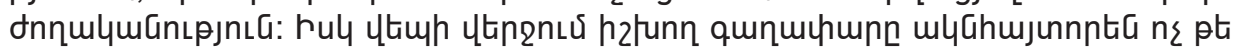

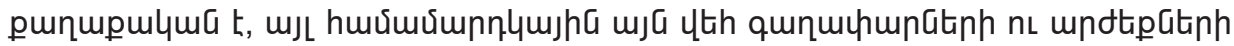

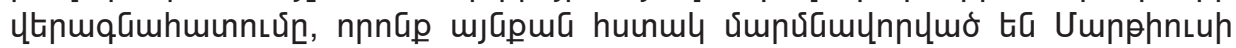
4tinumunnıx: 